\title{
INTERVENTION AND THE MEANING OF "BOUND" UNDER FEDERAL RULE 24(a)(2)*
}

INTERVENTION is the procedural device enabling a third person to enter and to become a party to an action or proceeding. ${ }^{1}$ It is generally desired to protect interests which may be at stake ${ }^{2}$ or to save the time and expense that would be involved in an independent action. ${ }^{3}$ Rule 24 of the Federal Rules of Civil Procedure governs the usual cases of intervention in federal practice. ${ }^{4}$ It attempts to reconcile the demands of the intervenor with the traditional right of the original litigants to be free of outside interference. ${ }^{\cdot}$ Rule 24(a)

*Clark v. Sandusky, 205 F.2d 915 (7th Cir. 1953).

1. See, e.g., Rocca v. Thompson, 223 U.S. 317, 330-1 (1912) ; First Nat'l Bank v. M \& G Convoy, Inc., 102 F. Supp. 494 (W.D. Pa. 1952) ; In re Willacy County Water Control and Improvement Dist., 36 F. Supp. 36 (S.D. Tex. 1940). For an extensive discussion of intervention, see 4 MOORE, Federal Practice $\Uparrow 24$ et seq. (2d ed. 1950) (hereinafter cited as MOORE).

2. See, e.g., Virginia Electric \& Power Co. v. Carolina Peanut Co., 186 F.2d 816 (4th Cir. 1951) ; United States v. E. I. DuPont \& Co., 13 F.R.D. 487 (N.D. Ill. 1953) ; First Nat'l Bank v. M \& G Convoy, Inc., 102 F. Supp. 494 (W.D. Pa. 1952).

3. See 4 MOORE (I 24.10; Note, Intervention of Private Parties Under Federal Rule 24, 52 CoL. L. REv. 922 (1952).

4. See, e.g., Root Refining Co. v. Universal Oil Products Co., 169 F.2d 514, 524 (3d Cir. 1948), cert. denied, 335 U.S. 912 (1949); United States v. E. I. du Pont \& Co., 13 F.R.D. 487 (N.D. Ill. 1953) ; Tolliver v. Cudahy Packing Co., 39 F. Supp. 337 (E.D. Tenn. 1941.). Yet Rule 24 is not "a comprehensive inventory of the allowable instances for intervention." Missouri-Kansas Pipe Line Co. v. United States, 312 U.S. 502, 505 (1941). This was an antitrust action in which intervention was granted as a matter of right according to the terms of a consent decree naming the applicant as one who should be heard under specified circumstances. Compare System Federation No. 91 v. Reed, 180 F.2d 991, 998 (6th Cir. 1950) (intervention granted where the consent decree protected all members of the applicant's class, although intervention was not specifically provided for), with Allen Calculators v. National Cash Register Co., 322 U.S. 137, 141 (1944) (intervention denied because consent decree failed to provide for it). See also Société, etc. v. McGrath, 17 F.R. Serv. 24a.2, case 3 (D.D.C. 1952) (an alternative ground for granting intervention was that the case was highly unusual; Missouri-Kansas Pipe Line Co. v. United States, supra, was cited).

Rule 24, although applicable to some cases of intervention in bankruptcy procecdings, yields to $\S \S 206-07$ of the Bankruptcy Law when there is a conflict. In re Bender Body Co., 2 F.R.D. 413 (N.D. Ohio 1942). Bankruptcy represents a special category of intervention problems. See 4 MOORE $\{24.11$.

For discussion of intervention in state practice, see Clark, Code Pleading 420-23 (2d ed. 1947); Note, 25 VA. L. Rev. 606 (1939).

5. See Berger, Intervention by Public Agencies in Private Litigation in the Federal Courts, 50 YALE L.J. 65 (1940). Intervention is the child of continental doctrines of equity. See Note, 25 VA. L. Rev. 606 (1939). It was unknown to early common law; the plaintiff enjoyed complete control of his action. See 2 Chitty, General Practice 493-4 (1835). The influence of this concept has been felt in this century in jurisdictions which have not 
sets forth the requirements for "intervention of right." 1 It serves a protective function for the applicant who may be injured unless heard in the action.? Out of fairness to the applicant, considerations of procedural efficiency and of inconvenience to the original parties are prohibited from influencing the decision as to intervention of right. ${ }^{8}$ But these considerations do come into play under 24(b), which governs "permissive" intervention." Even when not necessary for protection, intervention is often desirable to settle all related controversies, as far as possible, in one action. ${ }^{10}$ And $24(\mathrm{~b})$ gives the trial judge broad discretion to weigh in each case the various factors affecting trial convenience and fairness. ${ }^{11}$

Most cases of intervention of right arise under Rule 24(a)(2) because of

adopted the union of law and equity. See, c.g., Consolidated Liquor Co. v. Scotello \& Nizzi, 21 N.M. 485, 4945, 155 Pac. 10S9, 1093 (1916), where the court said that, "[t]he fundamental principle underlying legal procedure is that parties to a controversy shall have the right to litigate the same free from the interference of strangers."

6. FED. R. CIv. P. 24(a) provides: "Upon timely application anyone shall be permitted to intervene in an action: (1) when a statute of the United States coniers an unconditional right to intervene; or (2) when the representation of the applicant's interest by existing parties is or may be inadequate and the applicant is or may be bound by a judgment in the action; or (3) when the applicant is so situated as to be adversely affected by a distribution or other disposition of property which is in the custody or subject to the control or disposition of the court or an officer thereof."

7. See Virginia Electric \& Power Co. v. Carolina Peanut Co., 186 F.2d 816 (4th Cir.

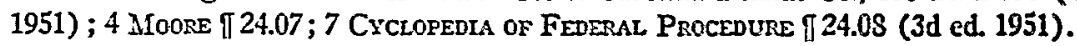

8. See Berger, supra note 5 , at 65.

9. FED. R. CIv. P. 24(b) provides: "Upon timely application anyone may be permitted to intervene in an action: (1) when a statute of the United States confers a conditional right to intervene; or (2) when an applicant's claim or defense and the main action have a question of law or fact in common. ... In exercising its discretion the court shall consider whether the intervention will unduly delay or prejudice the adjudication of the rights of the original parties." See note 11. infra.

10. See United States v. American Surety Co., 142 F.2d 726 (2d Cir. 1944). Elimination of multiplicity of actions is a general policy of the Federal Rules. Wheston, Fcderol Rules of Civil Procedure Interpretcd, 25 Corr. L.Q. 28, 29 (1939); Willis, Proccdure in: Patent Cases ander the New Federal Rules, 30 GEo. L.J. 348, 358 (1942). Rule 24(b) should be-and is-liberally construed in order to carry out this policy. Western States Machine Co. v. S. S. Hepworth Co., 2 F.R.D. 145 (E.D.N.Y. 1941). Professor Moore has stated that "in many cases where intervention might be denied as an absolute right, it would seem desirable that the trial court exercise its discretion and allow intervention." 4 MOORE $\prod 24.08$.

11. See, e.g., Allen Calculators v. National Cash Register Co., 322 U.S. 137 (1944) (intervention denied where representation adequate, the issues thoroughly explored and the case would otherwise be delayed); Kind v. Marlham, 7 F.R.D. 265 (S.D.N.Y. 1945) (intervention denied because it would complicate the case and shed no new light on it); Utica, C. \& S.V. Ry. v. Delaware, L. \& W.R.R, S F.R. Serv. 2432, case 3 (N.D.Y.Y. 1945) (intervention denied where it would involve unwarranted interierence in corporate affairs of the original parties). See also Heard in Feneral Rules of Cruz Proctours, Proceenings of the Institute at Washington, D.C. 136 (1939). For a discussion oi Rule 24(b), see Commentary, 3 F.R. Serv. 704 (1940). 
its generalized scope.12 It provides for intervention "when the representation of the applicant's interest by existing parties is or may be inadequate and the applicant is or may be bound by a judgment in the action."13 Although the word "bound" denotes the crucial prerequisite to intervention of right, ${ }^{14}$ it has not been accorded careful judicial analysis. ${ }^{15}$

It is generally held that an applicant may be "bound" within the meaning of Rule 24(a) (2) only when he may be subject to res judicata. ${ }^{10}$ This can

12. Rule 24 (a) (1) and Rule 24 (a) (3) are limited to special situations. See note 6 supra. Rule 24(a) (2) "purports to confer an additional right of intervention." Berger, supra note 5, at 87.

Only intervention by private parties under Rule 24 (a) (2) is discussed in this Note; for treatment of intervention by Government agencies, see Berger, supra note 5.

13. Cameron v. President and Fellows of Harvard College, 157 F.2d 993 (1st Cir. 1946); MacDonald v. United States, 119 F.2d 821. (9th Cir. 1941), modified on other grounds sub nom. Great Northern R.R. v. United States, 315 U.S. 262 (1942); Tolliver v. Cudahy Packing Co., 39 F. Supp. 337 (E.D. Tenn. 1941); see note 6 supra.

14. Although the applicant must also make timely application and show that the representation of his interest may be inadequate, it is customary first to inquire whether he may be bound. See, e.g., Sutphen Estates, Inc. v. United States, 342 U.S. 19 (1951); Cameron v. President and Fellows of Harvard College, 157 F.2d 993 (1st Cir. 1946); Wolpe v. Poretsky, 144 F.2d 505 (D.C. Cir.), cert. denied, 323 U.S. 777 (1944). See also United States v. Columbia Gas \& Electric Corp., 27 F. Supp. 116 (D. Del. 1939), quoted in note 16 infra. "The absolute right to intervene under F.R. 24(a) (2) is predicated on the fact that the petitioner will be bound by a decree of the court before which he is not adecquately represented." Clark, Code Pleading 425 (2d ed. 1947).

15. See 7 Cyclopedia of Federal Procedure $\llbracket 24.16$ (3d ed. 1951). Courts often treat Rule 24 briefly, e.g., American Brake Shoe \& Foundry Co. v. Interborough Rapid Transit Co., 1.12 F.2d 669 (2d Cir. 1940) ; Palmer v. Guaranty Trust Co., 111 F.2d 115 (2d Cir. 1940)—and sometimes cryptically, e.g., Deauville Associates, Inc. v. Eristavi-Tchitcherine, 173 F.2d 745 (5th Cir. 1949).

16. E.g., Sutphen Estates, Inc. v. United States, 342 U.S. 19 (1951); Innis, Speiden \& Co. v. Food Machinery Corp., 2 F.R.D. 261 (D. Del. 1942) ; Owen v. Paramount Productions, Inc., 41 F. Supp. 557 (S.D. Cal. 1941). "A natural meaning would of course be that [the words 'is or may be bound by a judgment in the action'] imply res judicata." 7 Cyclopedia of Federal Procedure $\{24.16$ (3d ed. 1951).

Because of the difficulty in many instances of foretelling whether or not the decree will be res judicata against the applicant, intervention should be granted, if other prerequisites are met, whenever there is a possibility of res judicata. Innis, Speiden \& Co. v. Food Machinery Corp., supra, at 265. Cf. Cameron v. President and Fellows of Harvard College, 157 F.2d 993, 996 (1st Cir. 1946). For an overly cautious approach resulting in misapplication of this principle, see Société, etc. v. McGrath, 17 F.R. Serv. 24a.2, case 3 (D.D.C. 1952).

The equating of bound with res judicata is sometimes expressed in terms of representation. Rule 24(a) (2) "relates to cases in which the applicant for intervention has an interest in the action represented by a party so that the applicant may be bound by a judgment in the action. The question of adequacy of representation does not arise unless the applicant is represented in the action." United States v. Columbia Gas \& Electric Corp., 27 F. Supp. 116, 119 (D. Del. 1939). It is generally said that $24(a)(2)$ is thus limited in its application to technical representative actions, such as the true and hybrid class suits provided for in Rule 23 (a), which also refers to adequate representation. CLARK, 
happen in two situations: where the applicant's rights are derived from the same source as a litigant's and he raises the same issues ${ }^{17}$ as, for example, when he is a stockholder attempting to intervene in a derivative suit against his corporation $;^{18}$ or where he is a privy of a litigant, ${ }^{10}$ as when he is the assignee of one who, by the assignment, violated an injunction. .0 The rationale is that the protection afforded by intervention of right is not essential to one who will have another legal remedy available after judgment..1

Code Pleadrang 425 n.295 (2d ed. 1947) ; 4 Moore $\llbracket 24.08$ n.1; Note, 55 Hunv. L. Rav. 264 n.27 (1941). This was the intent of the framers. See Clark: in Fenerul. Rules or CritL Procedure, Proceedings of the Institute at Cleveland 266 (1938). But, for the view that 24 (a) (2) applies to one who is totally unrepresented as well as to one represented to some degree, see Berger, supra note 5, at $\$ 6$.

17. E.g., System Federation No. 91 v. Reed, 180 F.2d 991 (6th Cir. 1950) (where applicants are non-union employees and non-union co-workers sue to enforce their rights under the union's contract with their employer) ; Wolpe v. Poretshy, 144 F.2d 505 (D.C. Cir.), cert. denied, 323 U.S. 777 (1944) (where applicants are property owners whose neighbors sue to void a zoning ordinance). See cases cited note 18 infra.

A decision cannot be res judicata for the applicant if the issues he seels to raise are dissimilar from those of the litigant; he is not bound since he is not represented in the action. Mullins v. DeSoto Securities Co., 2 F.R.D. 502, 504 (W.D. La. 1942), apfeal dismisscd, 136 F.2d 55 (5th Cir. 1943). See United States v. Columbia Gas \& Electric Corp., 27 F. Supp. 116 (D. Del. 1939), quoted in note 16 stipra.

18. E.g., Thompson v. Broadfoot, 165 F.2d 744 (2d Cir. 1948); Mialcolm v. Cities Service Co., 2 F.R.D. 405 (D. Del. 1942). But not every derivative suit raises the same issues as the stockholder-petitioner seels to litigate; where they are dissimilar, petitioner cannot be bonnd. See note 17 snpra.

19. E.g., Virginia Electric \& Power Co. v. Carolina Peanut Co., 186 F.2d 816 (4th Cir. 1951) (where, as insurer, petitioner has indemnified the insured who sues to recover from the tort-feasor) ; Park \& Tilford, Inc. v. Schulte, 160 F.2d 984 (2d Cir.), cert. dericd, 332 U.S. 761 (1947) (where petitioner is a stoclholder of a corporation involved in litigation) ; United States v. American Surety Co., 142 F.2d 726 (2d Cir. 1944) (where petitioner receives notice of a suit to be begun against his surety); Otis Elevator Co. v. Standard Construction Co., 10 F.R.D. 404 (D. Minn. 1950) (where petitioner's agent is sued in his capacity as agent) ; Innis, Speiden \& Co. v. Food MIachinery Corp., 2 F.R.D. 261 (D. Del. 1942) (where petitioner is an exclusive area licensee whose patentee sues another for infringement).

For a confusing and dubious application of Rule 24 (a) (2), see Kaufman v. Socięté, etc, 343 U.S. 156 (1952), where the Supreme Court held that non-enemy stoclsholders of a forcign corporation suing the Alien Property Custodian to recover assets vested on the theory it was enemy-dominated might be "bound" by the judgment, even though the Court declared that such non-enemy stockholders had a severable interest in the assets seized. For an analysis of this complicated case, see Comment, 62 Y ALE L.J. 1210, 1228 (1953).

For cases where intervention of right was denied because the applicant was not a privy of a litigant, see, c.g., Sutphen Estates, Inc. v. United States, 342 U.S. 19 (1951); Cameron v. President and Fellows of Harvard College, 157 F.2d 993 (1st Cir. 1946); Innis, Speiden \& Co. v. Food Machinery Corp., 2 F.R.D. 261 (D. Del. 1942).

20. Deauville Associates, Inc. v. Eristavi-Tchitcherine, 173 F.2d 745 (5th Cir. 1949).

21. See, e.g., Sutphen Estates, Inc. v. United States, 342 U.S. 19 (1951); Cameron v. President and Fellows of Harvard College, 157 F.2d 993 (1st Cir. 1946); White v. Hanson, 126 F.2d 559 (10th Cir. 1942); Republic of Italy v. DeAngelis, 18 F.R. Serv. 
Arguments that a judgment's practical effect will be highly prejudicial generally fail to convince courts to give "bound" a less rigorous meaning than res judicata. For example, the Supreme Court has held that an antitrust decree splitting the corporate defendant and reducing the assets which guaranteed the applicant's long-term lease to defendant's subsidiary did not "bind" the applicant. ${ }^{22}$ Where the amount of work given railroad firemen varied inversely with that given engineers, the firemen's union would not be directly "bound" by the judgment determining the amount of time engineers may work. ${ }^{23}$ And in a suit to enjoin violations of the Fair Labor Standards Act, milk haulers claiming to be independent contractors would not be "bound" by a decision that they were employees of the defendant, even though this might destroy the market value of their milk routes. ${ }^{24}$

24a.2, case 2 (S.D.N.Y. 1953). Cf. Wolpe v. Poretsky, 144 F.2d 505 (D.C. Cir.), cert. denied, 323 U.S. 777 (1944) (intervention granted because judgment would take away the applicant's right to an independent action) ; American Brake Shoe \& Foundry Co. v. Interborough Rapid Transit Co., 3 F.R.D. 162 (S.D.N.Y. 1942) (same). See Berger, supra note 5 , at 65 .

This is a carry-over from practice prior to Rule 24. Intervention was governed by Federal Equity Rule 37, which provided: "Anyone claiming an interest in the litigation may at any time be permitted to assert his right by intervention, but the intervention shall be in subordination to, and in recognition of, the propriety of the main proceeding." Despite the statute's permissive wording, appellate courts recognized intervention of right, often describing it in terms of abuse of discretion. Although they were sometimes confused, the vital factor in granting or denying the absolute right seems to have been the non-existence of another remedy. See, e.g., Jenkins Petroleum Process Co. v. Credit Alliance Corp., 83 F.2d 532 (10th Cir. 1936); Richfield Oil Co. v. Western Machinery Co., 279 Fed. 853 (9th Cir.), cert. denied, 260 U.S. 723 (1922) ; United States Trust Co. v. Chicago Terminal Transfer Co., 188 Fed. 292 (7th Cir. 1911). See also Wham, Intervention it Federal Equity Cases, 17 A.B.A.J. 160, 161 (1931); Willis, supra note 10, at 356; Commentary, 3 F.R. Serv. 704 (1.940).

Rule 24 explicitly recognized intervention of right, as well as permissive intervention, and dropped the limitation that both be in subordination to the original suit. As a corollary to the bound requirement of 24 (a) (2), it has been held that the trial judge's exercise of discretion under 24 (b) (2) will not be reviewed except where the applicant has no other adequate remedy. Cresta Blanca Wine Co. v. Eastern Wine Corp., 143 F.2d 1012 (2d Cir. 1944); Palmer v. Guaranty Trust Co., 111 F.2d 115 (2d Cir. 1940). Thus the fate of the applicant still turns upon the existence of another remedy.

22. Sutphen Estates, Inc. v. United States, 342 U.S. 19 (1951). The majority, speaking through Mr. Justice Douglas, denied intervention under $24(\mathrm{a})(2)$ because of petitioner's lack of privity with defendant. It saw "ample reason to prevent the administration of the decree from being burdened with a collateral issue that on this record can properly bc adjudicated elsewhere." Id. at 23.

23. See Brotherhood of Locomotive Engineers v. Chicago, M., St. P. \& P.R.R., 34 F. Supp. 594, 596 (E.D. Wisc. 1940).

24. Durkin v. Pet Milk Co., 14 F.R.D. 374 (W.D. Ark. 1953). The court stated that the "movants may be indirectly affected by a judgment . . . but they will not be 'bound" by the judgment in the sense contemplated by the Rule." Id. at 378. Because it recognized the practical effect which judgment might have upon the petitioners, the court permitted them to appear as amicus curiae in order to obtain representation by their own counscl. 
But a few cases have granted intervention under Rule 24(a)(2) where judgment could not be res judicata as to the applicant. A company official obligated to reimburse an insurer for all moneys paid out on its guarantee of the company's performance had "a vital interest" in the outcome of a suit against the insurer and the company for nonperformance because he would "in the last analysis ... [ [be bound] indirectly."25 Judgment against the defendants would render him ultimately liable unless he could show fraud, collusion, or failure to defend the suit properly. ${ }^{20}$ And where certificate holders sued the management of a trust estate containing cemetery property, a cemetery lot holder had an absolute right to intervene for purposes of appeal and re-trial when a decree replaced the trustees and enjoined all persons from interfering with the management of the new trustees and from suing the trust estate without leave of court. ${ }^{27}$ The Third Circuit stated that the petitioner's rights were "affected" by the decree since it purported to prevent him from freely asserting the prior lien of lot holders on a fund established for certificate holders. ${ }^{23}$

This practical approach to intervention of right has been supported by a few authorities. ${ }^{29}$ However, believing that the absolute right should not de-

This, it said, gave them all the advantages of intervention. Id. at 381. See also Kind $r$ Markham, 7 F.R.D. 265 (S.D.N.Y. 1945); Ocean S.S. Co. v. Allen, 36 F. Supp. 851 (II.D. Ga. 1941).

For other cases where intervention was denied because judgment could not be res judicata as to the applicant, see, e.g., Allen Calculators, Inc. v. National Cash Register Co., 322 U.S. 137 (1944) ; United States v. General Electric Co., 95 F. Supp. 165 (D.N.J. 1950); Baltimore \& Ohio R.R. v. Thompson, 8 F.R.D. 96 (E.D. Mo. 194\$); Jewell Ridge Cosl Corp. v. UNW, 3 F.R.D. 251 (W.D. Va. 1943) ; Keystone Freight Lines, Ine. v. Pratt Thomas Truck Lines, Inc, 37 F. Supp. 635 (W.D. Olla.), apfcal dismisscd sub nom. International Brotherhood of Teamsters v. Keystone Freight Lines, Ine, 123 F.2d 320 (10th Cir. 1941).

25. United States v. C. M. Lane Lifeboat Co., 25 F. Supp. 410 (E.D.N.Y. 1938), aff'd on other grounds, 118 F.2d 793 (2d Cir.), appcal dismissed, 314 U.S. 579 (1941).

In Tatum v. Cardillo, 11 F.R.D. 585 (S.D.N.Y. 1951), an employer and its insurer were granted intervention under $24(\mathrm{a})(2)$ in an action by an employce to revicw a commissioner's order under a compensation act, because they would be liable for any award made in his favor and could therefore be adzersely affected by the judgment. Id. at 5\&6. Cf. Knapp v. Hankins, 106 F. Supp. 43 (E.D. Ill. 1952). But see Brotherhood of Locomotive Engineers v. Chicago, M., St. P. \& P.R.R., 34 F. Supp. 594 (ED. Wis. 1940), where the court declined to follow the $C$. M. Lane indireclly bourd interpretation of 24 (a) (2). "Such a construction would be quite a strain on the meaning of the words. ..." Id. at 596. The court permitted intervention under 24 (b) (2). Had this approach been employed in the Lane and Tatum cases, the desired result could have been achieved easily without resort to 24 (a) (2). In this sense the language of a trial judge granting intervention under 24 (a) (2) may be considered gratuitous, for in all such cases he may permit it in the exercise of his discretion. See First National Bank v. MI \& G Convoy, Inc, 102 F. Supp. 494 (W.D. Pa. 1952) ; Indian Refining Co. v. Dallman, 2 F.R. Serv. 24b.2, case 3 (S.D. IIl. 1940).

26. United States v. C. M. Lane Lifeboat Co., supra note 25.

27. Mack v. Passaic National Bank \& Trust Co., 150 F.2d 474 (3d Cir. 1945).

28. Id. at 476-7.

29. See Berger, supra note 5 , at $65 \mathrm{n.4}$. 
pend solely upon the non-existence of another remedy and that courts should consider the efficacy of other remedies and the injury which may occur if intervention is denied, they suggest an application of 24(a)(2) even broader than that found in the cases. They offer vague formulae providing for intervention of right whenever the applicant's interests are "seriously jeopardized"so or "the effect of the judgment would be prejudicial." 31

In the recent case of Clark $v$. Sandusky ${ }^{32}$ the Seventh Circuit granted intervention of right to one who could not have been harmed by the judgment either legally or practically, in an overreaching application of the "prejudicial effect" definition of "bound." Negro citizens were suing the town of Cicero and its police officers for violation of their constitutional rights. They asked for an injunction against further interference with their alleged right of occt1pancy of an apartment building and for $\$ 200,000$ damages. Plaintiffs alleged that they leased the apartment and attempted to install their furniture but that defendants prevented them, by assault, abuse, and threats, from entering the premises. Mrs. Camille DeRose applied for leave to intervene as of right before trial. She claimed to be owner of both the building and the furniture and alleged that plaintiffs had no property interest in either. She asked judgment against both plaintiffs and defendants on the ground that her building had been damaged and boarded up on court order and her furniture destroyed as a result of plaintiffs' conspiracy to foment civil strife combined with the acts of defendants. The district court denied the application, ${ }^{33}$ but the Seventh Circuit reversed on appeal. ${ }^{34}$ The court recognized that the judgment could not bind Mrs. DeRose and that she would in fact be free to assert her claims in an independent action against all the original parties. ${ }^{35}$ Nevertheless, it held she was entitled to intervene under Rule 24(a)(2) because her rights "may well be substantially prejudiced" if not heard. ${ }^{36}$

30. Ibid.

31. 7 Cyclopedia of Federal Procedure f 24.16 (3d ed. 1951). The editors reject 24 (a) (2)'s "natural meaning" of res judicata-see supra note 15-for "a more rational point of view for the purposes at stake," which construes the words is or may be bound so that "they merely carry into present practice the orthodox requirement of intervention practice generally that the nature of the intervenor's interest must be such that he will gain or lose by the operation of the judgment."

32. 205 F.2d 915 (7th Cir. 1953).

33. Clark v. Sandusky, Civil No. 51-C-951, N.D. Ill., February 2, 1953.

34. Clark v. Sandusky, 205 F.2d 915 (7th Cir. 1953).

35. Id. at 918 .

36. Id. at 919. Judge Lindley admitted "some difficulty" with the requirement that Mrs. DeRose be bound. However, he found that she met the requirement of inadequatc representation "unquestionably" because "she asserts a claim adverse to both plaintiffs and defendants.... Thus she is not represented by any of the original parties and is clearly within the purview of the Rule." Id. at 918. For support he cited Deauville Associates, Inc. v. Eristavi-Tchitcherine, 173 F.2d 745, 746 (5th Cir. 1949). See sitpra note 20. Language in that opinion, after establishing that the petitioner would be bound because of privity, implied that no representation is inadequate representation. This illustrates why Professor Moore 
Little quarrel may be had with those few cases granting intervention of right where the judgment, although not conclusive of petitioner's legal status, could leave him at a practical disadvantage. ${ }^{37}$ But the facts of the Clark case seem not to bring it within that category. The court pointed out that Mirs. DeRose claimed the property involved and that this property was badly damaged or destroyed. From this it concluded that she "will certainly be materially affected if she is not permitted to participate in the action and assert her claim. ..."38 It is difficult to understand how she could be so affected, especially when, by the court's own admission, ${ }^{39}$ no practical obstacles prevented the use of her independent remedy against all the parties.to

Extension of intervention of right to those cases in which it is not imperative for purposes of protection will unnecessarily limit the flexibility of Rule 24.41 It will seriously curtail the discretion of the trial court by requiring it to grant intervention without further inquiry in many cases which presently fall under 24(b). Upon a minimal showing of interest by the applicant, the trial judge will be foreciosed from taking into account the most expeditious manner of handling the particular action, the effect of intervention on the rights of the original parties, or any similar considerations. ${ }^{42}$

states that it is preferable to approach 24 (a) (2) in terms of bousnd than in terms of representation of an interest, a hazier concept. 4 MOOnE $\mathbb{1 1} 24.08$ and $n .7$.

An applicant is represented within the meaning of Rule 24(2) (2) when the interest which he wants to assert is already before the court. See Campbell, Jurisdiction and V cuus Aspects of Interzention under Federal Rule 24, 7 U. of PIrT. L. Rev. 1, 9 (1940). In this sense if he is not represented to some degree, he is not eligible to intervene. See note 15 supra. Thus, in Sutphen Estates, Inc. v. United States, 342 U.S. 19 (1951), the Supreme Court held that 24(a) (2) could not apply where the petitioner's interest was adverse to the interests of the parties. See note 21 stpra. The Seventh Circuit drew the opposite conclusion from a similar situation. Misconstruction of representation led it to extend 24(2) (2) far beyond the class action typical of its intended application.

37. See case cited note 27 supra and accompanying text.

38. Clark v. Sandusky, 205 F.2d 915, 91\$-19 (7th Cir. 1953).

39. See text at note 35 supra.

40. By granting intervention of right when the applicant had another adequate remedy available, the Seventh Circuit held squarely against the long line of authority suggested by the cases cited in the first paragraph of note 21 supro.

41. This would be contrary to one of the purposes of the Federal Rules, which were designed to promote procedural flexibility. See 2 MLOOsE II 1.03; Wheston, suspra note 10, at 29 .

42. Although it is often assumed that allowance of intervention cannot hinder trial procedure nor harm the original litigants, there has been some judicial rccognition to the contrary. "There is a general practice in this and other Federal Courts to talse a liberal view towards motions to intervene, upon the apparent assumption that no substantial harm results from the granting of such motions. It is apparently felt that if the intervenor does not have a substantial right or interest in the proceedings, the ultimate disposition of the case will eliminate him without injury to the principal parties. This court feels, however, that petitions or motions to intervene should be carefully scrutinized and granted only in cases in which there is either a legal right to intervene or in cases in which the motion definitely establishes that the petitioner has some interest or right which will not be ade- 
This weakening of the discretionary authority of the trial court will be coupled with an inevitable increase in the work of appellate courts. The more ambiguous and expansive the criteria for intervention of right, the greater the temptation for unsuccessful applicants to appeal. Although there can be no objection to adding to the burden of the courts when positive justification exists, such justification is lacking here. ${ }^{43}$

And broad application of Rule 24(a) (2) will impose hardship upon the original parties. Rule 24(b) commands the court in the exercise of its discretion to consider whether or not intervention will unduly delay or prejudice their rights. ${ }^{44}$ Since the expansion of 24 (a) necessarily means the contraction of 24(b), original litigants will be deprived of the opportunity to have their interests affect the decision on intervention in more cases than under the present interpretation. They frequently will be burdened with interjection of other parties and other issues where previously they were unencumbered. ${ }^{45}$

When intervention is denied by the trial judge, the greater number of appeals encouraged by the Clark criterion will aggravate the dilemma of the partieswhether to defend against the appeal, spending additional resources before trial on the merits, or to resign themselves to the probability of losing control of the suit. ${ }^{46}$ And even if the intervenor loses his appeal, the action is often

quately protected or enforced unless intervention is granted." Tamm, J., in Société, etc. v. McGrath, 90 F. Supp. 1011, 1012 (D.D.C. 1950), appeal dismissed sub nom. Kaufman v. Société, etc., 188 F.2d 1017 (D.C. Cir. 1951), rev'd on other grounds, 343 U.S. 156 (1952). Judge Learned Hand recognized that certain "practical considerations" such as "the danger of confusion arising from the presence of too many parties, and the possible increases in the allowances and costs" might influence a trial judge to deny intervention. Manufacturers Trust Co. v. Kelby, 125 F.2d 650, 655 (2d Cir.), cert. denicd, 316 U.S. 697 (1942). See also cases cited note 11 supra.

43. Appellate review of such questions would result in the mere substitution of one opinion for another with respect to a controversial, but relatively unimportant, question of fact. Where this is the case, it is good policy to leave the decision to the trial judge. "Plainly enough, the circumstances under which interested outsiders should be allowed to become participants in a litigation is, barring very special circumstances, a matter for the nisi prines court." Frankfurter, J., in Missouri-Kansas Pipe Line Co. v. United States, 312 U.S. 502, 506 (1941).

44. See note 9 supra.

45. The original parties cannot appeal the granting of intervention until the case has gone to judgment on the merits because until then their rights are not determined. Sorenson v. United States, 160 F.2d 938 (2d Cir. 1947). As a practical matter, this eliminates the possibility of relief. For a brief analysis, see Note, 52 Col. L. Rev. 922, 930-1 (1952).

46. The instant case provides an example. Plaintiffs in Clark v. Sandisky opposed the attempt to intervene but did not defend against the appeal. Without the aid of appallce's brief, the Seventh Circuit was persuaded to grant intervention. Intervention here will undoubtedly alter the character of the action, causing its emphasis to shift from the civil rights issues originally involved to the collateral property dispute between plaintiffs and the applicant. Mrs. DeRose has vividly outlined her viewpoint in a book, Tre Caurule DEROSE STORY (1953).

If intervention were discretionary in the Clark situation, as the district court obviously thought, it could have been denied in order to prevent burdening the original action with 
delayed considerably.47 Whatever happens, the satisfaction which the parties derive from resort to the courts is diminished. An interpretation of "bound" which adds to their problems can only be justified where necessary for the protection of third persons.

But application of Rule 24(a) (2) only to those situations where the judgment may be res judicata or where the alternative remedy will be of no practical value assures adequate protection to third persons. ${ }^{48}$ Although the rejected applicant may be inconvenienced, he can suffer no significant injury if a practical alternative remains. The function of $24(a)(2)$ is to protect third parties, not to favor them. If protection is otherwise assured, intervention should be left to the discretion of the trial judge in order to foster Hexibility and fairness. Any rule superficially more liberal will only prove illiberal in its effect upon federal procedure and the rights of original parties.

collateral issues. See, c.g., United States v. Bendix Home Appliances, Inc, 10 F.R.D. 73 (S.D.N.Y. 1949); Baltimore \& Ohio R.R. v. Thompson, \& F.R.D. 96 (ED. MO. 1948); United States v. 1830.62 Acres of Land in Botetourt County, 51 F. Supp. 158 (W.D. Va. 1943).

47. For example, intervention was denied by the District Court in Clarl: a. Sardissly on February 2, 1953. The applicant filed notice of appeal four days later, but the appeal was not decided until July 20, 1953, delaying the case almost six months. Cf. Allen Calculators v. National Cash Register Co., 322 U.S. 137, 142 (1944), where MIr. Justice Roberts recognized the undesirability of "unwarranted appeals by disappointed applicants to intervene."

48. It is consistent with what Professor Moore calls, "the underlying principle in the development of intervention: the purpose of the courts to prevent their processes from being used to the prejudice of the rights of interested third persuns." 4 MIcone I24.03. 